\title{
BRIEF CONSIDERATIONS ON THE FINANCIAL CRISIS AND INSOLVENCY OF THE ADMINISTRATIVE-TERRITORIAL UNITS IN THE VIEW OF THE NEW REGULATIONS
}

\author{
E.N. Vâlcu, I. Didea, G. Popa
}

\section{Elise-Nicoleta Vâlcu}

Faculty of Law and Administrative Sciences

University of Piteşti, Piteşti, Romania

* Correspondence: University of Piteşti, Faculty of Law and Administrative Sciences, 71 Republicii Blvd., Piteşti, 110014, Romania

Email: elisevalcu@yahoo.com

\section{Ionel Didea}

Faculty of Law and Administrative Sciences

University of Piteşti, Pitești, Romania

* Correspondence: University of Piteşti, Faculty of Law and Administrative Sciences, 71 Republicii Blvd., Piteşti, 110014, Romania

Email: prof.didea@yahoo.com

\section{George Popa}

"Ovidius" University, Constanța

* Correspondence: George Popa, 1 Aleea Universității St., Constanța, Romania

\begin{abstract}
:
The reason for which the Government Emergency Ordinance No 46/2013 regarding the financial crisis and insolvency of administrative-territorial units is the fulfillment of the obligations assumed by Romania in order to reduce the overdue registered by the administrative-territorial units to their suppliers of goods, services and works. The article aims to analyze the general framework and the procedures regarding the coverage of the liability and the financial recovery of the administrative-territorial units which are in a financial crisis or in insolvency, relating to the general framework for insolvency, namely Law No 85/2006, as well as the Law No 273/2006 regarding local public finances updated and amended by Law No 13/2011.

Key words: financial crisis, insolvency, financial recovery plan, main credit release authority, bankruptcy judge, National Register for the Insolvency Cases of the administrative-territorial units

\section{Introduction}

The normal performance of the commercial activity requires that all professionals who have assumed contractual obligations to respect them according to their provisions. The nonperformance of the obligations, in general, especially of the financial ones, at their expiration, produces negative consequences not only for the creditor, but also for the other merchants with whom the creditor has legal relations, in the meaning that the nonpayment of the obligations assumed according to the contract by the debtor have chain consequences also for other merchants, finally leading to a financial blockage with serious effects against the security of the credit, one of the economic pillars.

The nonperformance of the financial obligations at their expiration can be determined by the lack of liquidities of the merchant-debtor caused by financial difficulties.
\end{abstract}


In such situation it is raised the question regarding the treatment applicable for this category of merchants. In the support of finding the answer, the Romanian legislatior brings its contribution, in the meaning that after 1989, when the market economy has been introduced, was adopted the Law No 64/1995 on the procedure of reorganization (the notion "recovery" is the terminological equivalent of the same notion from the French law) and judicial liquidation (the notion "liquidation" is the modern equivalent of the notion of "bankruptcy").

Under the impact of the critics arguing the abandonment of the institution of bankruptcy, the title of the Law No 64/1995 was modified by Government Emergency Ordinance No 58/1997 becoming the law "on the procedure of reorganization and bankruptcy". After 10 years, the Law No 64/1995 was abrogated and replaced by Law No $85 / 2006$ on the procedure of insolvency ${ }^{1}$.

The new law is mostly a reproduction of the Law No 64/19952, substantial modifications being made for practical considerations ${ }^{3}$.

Law No 85/2006 is completed, to the extent of their compatibilities, with the New Code of Civil Procedure, New Civil Code and Regulation (EC) No 1346/2000 on insolvency proceedings.

Yet even this last variant is not considered satisfactory because it does not include preventive proceedings that will allow the avoidance of the debtor's insolvency, as other EU legislations state. These legislative gaps were removed by the adoption of Law No 381/2009 regarding the preventive concordat and the ad-hoc mandate . $^{5}$

The insolvency stated by Law No 85/2006 is general and does not refer to autonomous administrations or to the administrative-territorial units, for which the legislator states special provisions ${ }^{6}$.

\section{Comparative analysis regarding the concepts of financial crisis and insolvency in the view of the G.E.O No 46/2013 on financial crisis and insolvency of administrative-territorial units}

\section{A) The financial crisis of the administrative-territorial units}

G.E.O No 46/2013 emerged in the context of the imminence of a new stand-by agreement with the International Monetary Fund. In order to conclude this agreement, Romania had to reduce the maturing debts to services, assets and works suppliers.

This regulation states the general framework and the proceedings for covering the passive and for the financial recovery of the administrative-territorial units found in a financial crisis or in insolvency.

Art 2 of the G.E.O No 46/2013 is reserved for definitions, namely financial crisis $^{7}$ and insolvency.

From the analysis of Art 2 Let $\left.\left.\mathrm{m}^{1}\right), \mathrm{m}^{2}\right), \mathrm{r}^{1}$ ) and $\mathrm{r}^{2}$ ), both the financial crisis, as well as the insolvency are those conditions of the patrimony of administrative-territorial units,

\footnotetext{
${ }^{1}$ Official Gazette of Romania No 359/21 April 2006

${ }^{2}$ Stanciu Cărpenaru, Tratat de drept comercial român, 3rd Edition reviewed according to the New Civil Code, Universul Juridic Publishing House, Bucharest, 2012.

${ }^{3}$ It mostly aims the creation of a simplified procedure applicable for merchants found in special situations or for those who have declared by an application their intent to go bankrupt, was amplified the role of the creditors' assembly and of the creditors' committee for the application of the procedure, were enlarged the responsibilities for the judicial administrator and liquidator, are reduced some terms in which the procedural documents must be filled in, is simplified the procedure of summoning, notification and communication in the National Bankruptcy Register.

${ }^{4}$ Published in the EU Official Journal No L 160/30 June 2000.

${ }^{5}$ Official Gazette of Romania, No 870/14 October 2009.

${ }^{6}$ Law 503/2004 on the financial recovery and bankruptcy of insurance undertakings is applicable for the insurance companies; Government Emergency Ordinance No 10/2004 on bankruptcy of credit institutions is applicable for credit institutions, the ordinance being completed and amended by Law No 278/2004.

${ }^{7}$ The financial crisis was previously stated by Art 74 of the Law No 273/2006 on local public finances.
} 
characterized by the existence of a financial difficulty, by the serious lack of financial liquidities, which leads to the impossibility to perform their obligations, liquid and on term for a certain time.

Specifically, the difference between these two notions (financial crisis and insolvency) is represented by the fact that the financial crisis is presumed in the following situations: a) noncompliance with the payment obligations, liquid and on term, older than 90 days and exceeding $15 \%$ of the annual budget of that administrative-territorial unit; b) noncompliance with the salary rights stated in the budget of incomes and expenses for over 90 days from their term, while the insolvency is the situation of the administrative-territorial unit, characterized by the insufficiency of the funds available for paying the debts on term and is presumed in the following cases: a) noncompliance with the liquid and on term payment obligations older than 120 days and exceeding $50 \%$ of the annual budget, without considering those in litigation; b) noncompliance with the salary rights stated in the budget of incomes and expenses for over 120 days from their term.

A closer analysis of the text reveals that the procedure of financial crisis is not a judicial one, but a pure administrative one triggered by the deliberative authority, which, after taking this decision, empowers the credit accountant to draw a project for a financial recovery plan.

It must also be emphasized the fact that procedure of financial crisis does not represent a mandatory stage previous to insolvency. If the requirements for insolvency are met, the administrative-territorial unit shall be declared insolvent, without a previous initialization of the procedure of financial crisis.

Art 3 of the G.E.O No 46/2013 states the idea that while a large category of persons stated by Art 74 of the Law No 273/2006, namely the main credit accountant of the administrative-territorial unit, the chief accountant of the local public authorities, secondary or tertiary authorizing officers from the public services subordinated to local councils, different creditors etc., have only the ability to inform about the financial crisis, only the main credit accountant has the obligation to inform about the financial crisis, otherwise he shall be sanctioned according to Art 114 Para 1 of the G.E.O No 46/2013.

Within 5 days from the adoption of the decision stating the crisis by the deliberative authority, the main credit accountant has to request its registration in the local register of financial crisis of the administrative-territorial units, managed by the county general directorates of public finances, or of Bucharest. The situations in which a financial crisis is opened or closed are monthly communicated to the Ministry of Public Finances.

Also, within the term of 5 working days from the adoption of the decision which declared the financial crisis, shall be formed the committee for situations of financial crisis, by order of the prefect. The Committee shall be convoked by the prefect and shall be formed by: the mayor or the president of the county council; the chief accountant; the manager of the public service of local interest which generated the financial crisis, if necessary; a representative of the general directorate of county or Bucharest public finances; a representative of the associated structure of the local public authorities from whose category the concerned administrative-territorial unit is part.

Within 30 days from the adoption of the decision which declared the financial crisis it shall be elaborated the plan for financial recovery by the main credit accountant together with the members of the committee for situations of financial crisis, with the approval of the county chamber of accounts.

Art 3 Para 2 of the G.E.O No 46/2013 states that the deliberative authority empowers the main credit accountant to draft the project of the financial recovery plan, and Art 5 Para 3 states that the plan is elaborated in common by the main credit accountant and the members of the committee for crisis situations. In these conditions, it can be concluded that the main credit accountant drafts a project of the plan, and then the elaboration is made based on that project. 
Of course it can be raised the issue of the duration of elaboration of this project, because G.E.O No 46/2013 does not state anything about this.

The plan is approved by a decision of the deliberative authority based on the proposal submitted by the main credit accountant, according to Art 74 Para 9 of the Law No 273/2006, being submitted for approval to the deliberative authority within 3 days from its elaboration and shall be adopted within 5 days from its submission. It is shall not be adopted, the deliberative authority shall subject it to a reanalysis. If after the reanalysis is not adopted, it is considered to be adopted in its original form. As a conclusion, regardless of whether the deliberative authority adopts it or not, is shall be considered adopted anyway.

Monthly, the main credit accountant shall send a report regarding the evolution of the plan for the members of the committee and for the deliberative authority, and the Committee for crisis situations controls the accomplishment of the measures stated by the plan ${ }^{8}$.

The cessation of the financial crisis shall be declared by a decision of the deliberative authority, at the request of the main credit accountant with the advisory opinion of the committee for financial crisis situations, if: a) for 180 calendar days were not emphasized the criteria which determined the financial crisis; b) are met the criteria for declaring the insolvency, case in which the administrative-territorial unit is subjected to the procedure of insolvency.

\section{B) The insolvency of the administrative-territorial units}

In the procedure of the insolvency of the administrative-territorial unit the participants are different than the ones from the "common law" procedure of insolvency. According to art 5 of the Law No 85/2006 the participants in the common law procedure of insolvency are the courts, the syndic judge, the judicial administrator and the liquidator. According to Art 14 of the G.E.O No 46/2013 the participants in the procedure of insolvency of the administrativeterritorial unit are all the above mentioned, plus the main credit accountant for that unit, the deliberative authorities (local councils of communes or cities, County Councils or the General Council of Bucharest), without the liquidator, because the present norm does not state the possibility of liquidating an administrative-territorial unit.

Regarding the causes to be decided for the insolvency are in the competence of the court in whose teritorial area that administrative-territorial unit is located, being trialed by a syndic judge.

The appeal against the decision of the court shall be trialed at the Court of Appeal, being submitted only for the reasons stated by Art 488 of the New Code of Civil Procedure ( 8 reasons for appeal), and the appeal court shall be able to annul and retrial under Art 498 of the same code.

The term of appeal is 10 calendar days from the communication of the decision, if the law does not state differently. The appeal is trialed by specialized panel of judges within 30 days from the submission of the case file to the Court of Appeal. In order to trial the appeal, shall be sent to the Court of Appeal, in copies certified by the chief-clerk only the documents concerning the resolution of the appeal, selected by the syndic judge. If the court of appeal considers necessary other documents from the initial case file, shall notify the parties to submit them in a certified copy.

The main attributions of the syndic judge ${ }^{9}$, according to the present law, are:

a) Issuing a motivated decision for the opening of the procedure of insolvency;

b) Judging the contestations stated by the administrative-territorial unit against the requests of the creditors to open the procedure;

\footnotetext{
${ }^{8}$ Art 10 of the G.E.O No 46/2013.

9 The attributions of the syndic judge are limited to the judicial control of the activity of the judicial administrator, to the trials and judicial requests regarding the procedure of insolvency. The managerial attributions belong to the judicial administrator or to the main credit accountant of the administrative-territorial unit if his right to exert the attribution of main credit accountant has not been suspended.
} 
c) The motivated appointment of a judicial administrator by the decision to open the procedure of insolvency, the establishment of his attributions, the control over his activity and, if necessary, his replacement;

d) Trialing the requests submitted by the judicial administrator to cancel the transfer of assets performed previous the opening of the procedure;

e) Judging the contestations submitted by the administrative-territorial unit or creditor against the measures adopted by the judicial administrator;

f) The admission and confirmation of the plan for financial recovery of the administrative-territorial unit;

g) Solving the contestations stated against the reports of the judicial administrator;

h) Establishing the suspension of the enforcement procedures against the administrativeterritorial unit;

i) Trialing the actions submitted by the judicial administrator for the suspension of the payments performed by the administrative-territorial units to its creditors after the declaration of insolvency and until the elaboration of the plan for paying the debts to the creditors;

j) Trialing the actions submitted by the judicial administrator and the Committee of creditors for the annulment of the fraudulent documents concluded by the main credit accountant;

k) Issuing the decision to close the procedure of insolvency.

Art 55 of the G.E.O No 46/2013 points out the documents to be submitted with the voluntary request to open the procedure of insolvency, among which we mention the list of the most important public services that the administrative-territorial unit must provide during the procedure. According to Art 56 of the G.E.O, if the list with the necessary documents is not attached to the case file in good time, the request to open the procedure of insolvency shall be rejected.

The creditors may oppose the decision to open the procedure of insolvency issued by the main creditor accountant.

If the request is expressed by the creditors ${ }^{10}$, the main credit accountant may submit an appeal. The failure to submit an appeal has as direct consequence the opening of the procedure of insolvency. Thus, according to Art 63: "if the administrative-territorial unit does not challenge the insolvency within the term stated by Art 60 Para 2, the syndic judge shall rule to open the procedure of insolvency.

The immediate effect of the opening of insolvency consists in the fact that all judicial or extra-judicial actions initiated against the administrative-territorial unit are suspended ${ }^{11}$.

The recovery plan exclusively aims the procedure of insolvency, because, in the hypothesis of the financial crisis of the administrative-territorial units, there is the plan of financial recovery, different than the recovery plan from the procedure of insolvency. This must state both a plan to pay the debts to the creditors, as well as measures aiming the restructuration of the administrative-territorial unit, restricting the administrative apparatus, giving up some investments etc.

The plan shall be elaborated by the judicial administrator together with the main credit accountant within 30 days from the appointment of the judicial administrator and shall be communicated by him to all the creditors, mentioning the date of the meeting of all creditors, which shall debate this plan.

\footnotetext{
${ }^{10}$ As an effect of the requests to join the statement of affairs expressed by the creditors shall be formed a table of claims which can be appealed both by the creditors, as well as by the administrative-territorial unit. This table is preserved by the clerk of the court.

${ }^{11}$ In this regard see Art. 66.
} 
In order to be adopted, the recovery plan must be approved by the Public Finances General Directorate of counties or Bucharest and by the Court of Accounts, also being necessary the approval of the deliberative authority.

The approval of the recovery plan shall be made the creditors' assembly, with the vote of the majority, representing two thirds of the value of debts.

\section{Conclusions}

We consider that this law represents a legislative normality imposed by the economic reality specific for the administrative-territorial units, entities having in the present of 2013 serious financial crisis generated on the one hand by the global financial crisis, and on the other hand by the agreements concluded between Romania and the International Monetary Fund.

\section{Bibliography}

G.E.O No. 46/2013 regarding the financial crisis and insolvency of administrativeterritorial units

S. Cărpenaru, Tratat de drept comercial român, $3^{\text {rd }}$ Edition reviewed according to the New Civil Code, Universul Juridic Publishing House, Bucharest, 2012

Law No. 13/2011 on the approval of the G.E.O No 63/2010 for the modification and amendment of Law No 273/2006 on local public finances, as well as for the establishment of certain financial measures

Law No. 85/2006 on the procedure of insolvency

Regulation (EC) No 1346/2000 on insolvency proceedings 